\title{
ВЕРИДБА И БРАК У ЦРКВЕНОМ СМИСЛУ ИЗ ПЕРСПЕКТИВЕ МЛАДИХ
}

\section{МАРИЈА ЛИГОЦКА СТЕФАНОВИЋ}

\section{THE MEANING OF ENGAGEMENT AND MARRIAGE IN THE ORTHODOX CHURCH FROM THE PERSPECTIVE OF YOUNG PEOPLE}

\begin{abstract}
The present article originated as an attempt to show how young Serbian people understand the idea of religion and marriage in the Orthodox Church. The aim of the present study is to find out whether adolescents are able to explain what is the true meaning and value of marriage and how it affects them. The research is a part of a grant project at University of Ostrava and is based on a questionnaire which served as an instrument to collect as much material concerning attitudes of young people towards religion as was needed.
\end{abstract}

KEY WORDS religion, understanding of religion, Orthodox Church, marriage, engagement

CONTACT Марија Лигоцка Стефбановић, Filozofická fakulta Ostravské univerzity; A18620@student.osu.cz

\footnotetext{
1 Чланак настао у оквиру реализације пројекта SGSO4/FF/2019-2020 Obraz sacrum v jazyce křestanské mládeže, Ostravská univerzita.
} 


\section{1 / УВОД У ПРОБЛЕМАТИКУ ТЕОЛИГНВИСТИЧКИХ ИСТРАЖИВАЊА}

Човекова заинтересованост верском, црквеном и религијском терминологијом током година постајала је све већа и дубља што је довело до стварања посебне гране лингвистике - теолингвистике. У научну употребу ушао је велики број речи и термина који су се односили на религију (језик Цркве, религијски стил итд.). Самим тим може се рећи да теолингвистика представља део лингвистике који је уско повезан са теологијом и религиологијом, а такође другим друштвено-хуманистичким наукама (Кончаревић 2017: 278). Ксенија Кончаревић наводи да проблеми теолингвистике обухватају већи број питања која се могу свести на неколико група. Прво, теолингвистика се бави питањем религијског језика тј. на који начин се религисјки појмови вербализују у језику. Следећи проблем којим се занима ова грана лингвистике односи се на сакралне текстове као и на њихову заштиту од деформација при ширењу и публиковању. Осим ових проблема, горе споменута ауторка наводи и проблем комуникације у сакралној сфери и начин на који верски медији утичу на формирање мишљења јавног мњења (Кончаревић 2017: 278).

Водећи се дефиницијом Гадомског, Кончаревић објашњава да је предмет теолингвистике пројава религије која је нашла своје место у језику, али исто тако и сам језик као форма религије и као начин манифестовања религијских садржаја. Ауторка такође наводи да је циљ теолингвистике „изучавање свега што је везано за сакралну сферу, а што је нашло одраз у језику и што је фиксирано самим језичким средствима, као и примена резултата добијених фундаменталинм истраживањима“ (Кончаревић 2017: 279).

Теолингвистика као засебна област лингвистике конституисана је 70-их и 80-их година XX века. Сам термин теолингвситика увео је у употребу белгијски лингвиста Жан-Пјер ван Нопен и објаснио да она настоји да објасни како и на који начин можемо употребити језик у обраћању Богу и какву фукнцију језик има у религијским ситуацијама. Међутим, особа која је итекако заслужна за промовисање овог термина је Дејвид Кристал. Он је термин теолингвистика унео у Кембриџову енциклопедију језика 1987. године и навео да се опус проучавања ове гране лингвистике односи на језик који употребљавају верници и стручњаци који се баве религијом (Кончаревић 2015: 60).

На словенској територији заинтересованост за појам теолингвистике (по мишљењу Ксеније Кончаревић) је без сумње највећа у Пољској, где се појавио велики број монографских дела, тематских зборника, зборника са научних скупова и студија. За дефинисање појма теолошка лингвистика и касније прихваћенијег термина теолингвистика, као и за његово ширење, највеће заслуге припадају Јанушу Данецком и Елжбјети Кухарској-Драјс. Године 1999. формирана је Комисија за језик вере која сваке две године организује научне скупове који су посвећени различитим аспектима проучавања језика вере и цркве (Кончаревић 2015: 56).

Што се тиче источнословенске средине, конкретно Украјине, како наводи Кончаревић, најзаслужнији за ширење термина теолингвистка је Александар Гадомски, који је уједно и аутор највећег броја публикација посвећених овој теми. Он је такође одговоран за увођење предмета Основи теолингвистике у студијске програме.

На територији Русије теолингвистика почиње да се шири захваљујући монографији Нине Борисовне Мечковске „Језик и религија“ (Кончаревић 2015: 59). 
У Србији се дуго није испољавала заинтересованост за ову област лингвистике све до 2012. године када се у Београду појавио први зборник Теолингвистика чији је аутор горе споменута Ксенија Кончаревић. Теолингвистика се на српском језичком подручју (што значи не само у Србији, али и у Црној Гори и Републици Српској) развила у различитим правцима и обједињује скоро све области истраживања које су обухваћене у другим словенским земљама. Радови који имају теолингвистички карактер објављивани су у разноразним часописима, нпр. у београдском часопису Богословље, Зборнику радова Матиие српске за фбилологију и теолингвистику у Новом Саду или часопису Филолог у Нишу, и многим другим (Кончаревић 2017: 285).

У овом чланку потрудићемо се - на основу властитих итраживања у виду анкете - да покажемо на који начин су нека религијска схватања вербализована од стране младих Срба. Реч је, конкретно, о релацији међу традицијом веридбе и венчања и њиховим религијским значењем.

\section{2 / РЕЛИГИЈА И ЊЕНО ПРИХВАЋАЊЕ}

Религија је комплексан људски феномен који није лако објаснити. Она је активан елемент људског живота. Такође, представља специфичан систем идеја, веровања и праксе и може се рећи да је својеврстан облик погледа на свет. Око саме религије постоји много спорова, јер може на различите начине да се схвата, различито се вреднује и на различите начине јој се приступа (Кубурић 2008: 56). Религија је, пре свега друштвена појава која се може јавити и ван појединца.

Речник српског језика дефинише религију као: „веровање у натприродне силе и бића од којих зависи свет, веровање у Бога (или богове) као ствараоца света који управља њиме; систем таквих веровања, вероисповест [...]“ (Речник српског језика 2011: 1133).

Религија може имати неколико функција. Она представља одређену врсту погледашна свет или иначе слику света, јер, по мишљењу Кончаревић, човек управо кроз религију покушава да разуме и гледа на ствари које га окружују. Под сликом света, како наводи претходно споменута ауторка, треба разумети уређен скуп знања о стварности који је настао у друштвеној свести. Поглед на свет је делимично универзалан и делимично специфичан за одређене народе. Он одражава културно релевантне ставове и мишљења и свака култура образује посебан оквир унутар којег се интерпретира реалност (Кончаревић 2017: 88).

Следећа функција религије је емоционална. Ова фукнција односи се како на позитивне тако и на негативне ствари у нашим животима, као што је нпр. смрт. Религија утиче на наше емоције и помаже нам да на неки начин рационализујемо своју патњу. Једна од најбитнијих фукнција које религија поседује је, засигурно, етичка функција, тј. религија има велику улогу у формирању основних моралних начела појединца. Будући да човек верује да ће га Бог у зависности од његовог понашања наградити или казнити, труди се да контролише своје кораке и поступа ускладу са начелима које религија приказује као исправна. Постоји још једна функција - друштвено-интегративна. Друштвено-интегративну улогу религија врши на тај начин што пружа један систем вредности и један поглед на свет који могу да уједине различите групе унутар једног друштва. Међутим, исто тако, религија може имати и дезинтеграциону функцију поготово у друштвима која нису религиозно хомогена 
Религије могу да се класификују на различите начине. По начину настанка, оне се могу поделити на природне, које не познају никакву религијску истину и у којима је човек сам својим схватањима и посматрањима дошао до неке истине, и откривене, тј. објављене религије чији је поглед вере записан у светим књигама и које проповеда и шири међи људима пророк (Кубурић 2008: 32).

Будући да се, како је раније споменуто, религија јавља изван појединца, религиозност је субјективна ствар и може се дефинисати као „субјективни систем ставова који укључује особите облике веровања, мишљења, осећања и тенденција реаговања, а јавља се и као систем унутрашњих трајних диспозиција које се манифестују било на вербалан, било на невербалан начин у понашању верника“ (Кубурић 2008: 38). Религиозност Кубурић разуме, психолошки, као део слике о себи и, социолошки, као део породичног ритуала и организације живота. Саставни део религије, како наводи Кубурић, представља веровање као систем верских знања о основним религијским појмовима и тезама којима се религија бави (Кубурић 2008:38).

\section{З / РЕЛИГИЈА У ОКВИРУ ПОРОДИЦЕ}

Социјална институција која је одувек била највише повезана са религијом је свакако породица. Управо је породица главни фактор и извор религиозног веровања. Кубурић наводи да „развојно посматрано, дететов социјални свет најпре је његова породица, а затим се тај свет постепено шири у географском, социјалном, верском погледу“(Кубурић 2008: 10).

Ако су родитељи припадници одређене религијске заједнице, самим тим ће вршити велики утицај на своје дете да и оно поштује ту исту заједницу, а такође да буде члан исте. Наравно, дешава се да, иако дете потиче из религиозне породице, може изабрати пут нерелигиозности тј. може бити атеиста. Међутим, по правилу, ако се дете родило у хомогено религиозној породици (што значи да оба родитеља поштују исту веру) и оно ће бити религиозно. У случају да један од родитеља припада другој верској заједници, деца ће бити поколебана и најчешће ће се одлучити за атеизам. Истина је да се у породици формирају први облици свести и понашања, стога је и логичан закључак да ће управо она (породица) имати највећи утицај на дете у одлуци за припадност одређеној верској заједници. Из истог разлога већина верника традиционално остаје верницима исте цркве којој су припадали и њихови родитељи (Кончаревић 2008: 13).

Претходно споменуто потврђује и анкета коју смо израдили на Остравском универзитету (и употребили у Србији), а која је настала у оквиру ширег истраживања. На питање да ли отац и мајка верују у Бога, одговори су углавном били потврдни. У случајевима где је један од родитеља био атеиста, испитаници су или избегавали одговор који се тиче њихове религиозности или су одговарали да не верују у Бога (у ретким случајевима и они су одговарали да верују). Ово потврђује речи Кубурић да када оба родитеља уче децу истим вредностима, религијски утицај има јачу снагу него када је дете оптерећено вредносним системима сваког родитеља понаособ (Кубурић 2008: 13).

Утицај који родитељи врше на своје дете по питању вероисповести, такође се одражава и на учење веронауке. Веронаука је у Србији уведена као изборни предмет, ${ }^{2}$ и већи-

2 Осим веронауке, деца у основним и средњим школама у Републици Србији могу да изаберу предмет Грађанско васпитање. 
на деце се опредељује за исту управо због родитеља и зато што се то од њих очекује. Циљ веронауке или науке о религији је да формира религиозна веровања код младих људи и да им на неки начин приближи веру и све што она обухвата.

\section{4 / ИСТРАЖИВАњА ОДНОСА МЛАДИХ ПРЕМА ТРАДИ- ЦИЈИ ВЕНЧАЊА И ВЕРИДБЕ}

У анкети, која је раније споменута, а чији је циљ да прикупи што више података који се тичу схватања и погледа младих на религију, испитано је, између осталог, и како млади разумеју црквено венчање и веридбу и који је њихов став према истим. Анкета је спроведена у новембру 2019. године на територији Србије. Испитаници су били ученици основних и средњих школа, старосне доби од 13 до 18 година, који су похађали (или нису) наставу веронауке. Испитано је укупно 150 ученика. Анкета је била анонимна и садржала је 28 питања. На питања је било потребно одговорити или заокруживањем понуђених одговора или је требало да ђаци сами напишу опширнији одговор. Питања су се односила на то да ли испитаници себе сматрају верницима, као и на то да ли су њихови чланови породица верници (под члановима породице подразумевани су отац и мајка као главне фигуре за које се сматра да усађују основне моралне вредности својој деци). Када је у питању вера коју исповедају, двоје деце од свих испитаника означила су да припадају другој верској заједници у односу на православну (и то једно дете припада заједници Јеховиних сведока, док је друго дете исламске вероисповести). Већи број испитаника, тачније 130 њих од укупног броја испитаних, и то углавном они који као изборни предмет имају веронауку, одговорили су да редовно иду у цркву и то углавном недељом, док неки осећају потребу за одлазак у цркву само за важне празнике као што су Божић, Васкрс итд. Ученици који нису похађали верску наставу, махом су одговарали да уопште не иду у цркву.

Занимљива је чињеница да место становања (град или село) није имало велику улогу у томе да ли испитаници одлазе редовно у цркву или не.

Осим овакве врсте питања, обраћена је пажња на појмове као што су веридба и венчање. Циљ оваквих питања је био да се из перспективе младих сагледају обичаји и обреди који су повезани са поменутим појмовима.

Једно од питања односило се на веридбу тј. испитаници је требало да изнесу своје мишљење о овом појму. Према обичајима, веридба је служила да се упознају родитељи, као и ужа породица пара који су одлучили да свој живот проведу у браку. Веридбе су се углавном дешавале у кући младе и то је био тренутак када је младожења званично тражио младину руку. На дан веридбе су се бирали кумови и други најближи људи који би требало да имају неку улогу на свадбеном весељу. Данас је сам чин вердибе изгубио значење какво је имао раније. Осим ове врсте веридбе, пре самог чина венчања одлази се код свештеника на Црквену веридбу (илити Предбрачни испит), која је већ раније споменута.

Одговори који се тичу овог појма углавном су били исти - већина младих је написала да, по њиховом мишљењу веридба представља следећи корак у вези између две особе (корак на путу према браку) а такође да је то знак (потврда) љубави између њих, израз сигурности, поуздања:

„То је следећи корак који двоје младих направи када су у вези.“ 
„Веридба је знак да смо спремни да своју вези подигнемо на виши ниво.“

„Када се двоје младих вери, то значи да су сигурни да цео свој живот желе да проведу са својим партнером.“

„Веридба је потврда љубави и знак да верујемо особи у коју смо заљубљени и да желимо да оснујемо породицу са њом.“

„Када се са неким веримо, то значи да смо сигурни у своју љубав и да потпуно верујемо тој особи.“

„Веридба је знак да желимо да се венчамо са неким“

Неки од испитаника су одговарали да за њих веридба нема никакав значај, док неки нису ни одговорили на ово питање.

Следеће питање односило се на чин венчања. Венчање у српској православној цркви обухвата велики број обичаја. Обред самог венчања, по црквеним правилима, треба да се обави у парохији из које потиче младожења. Пре самог чина, младенци су обавезни да иду на такозвани Предбрачни испит или Црквену вердибу. Овим испитом, свештеник који треба да венча младенце, утврђује се да ли младенци испуњавају све услове да склопе црквени брак, и тек након овог испита, уговара се датум венчања. ${ }^{3}$

С обзиром на то да се у православној вери поштује велики број постова, поштују се такође и правила када се заправо венчање може одржати. Среда и петак су скоро увек посни дани, ${ }^{4}$ и тим данима се обреди не одржавају. Пост, између осталог, представља суздржавање од порока, стога не приличи да се велика весеља праве у току истог. Осим средом и петком, како произилази из горе наведеног, венчања не би требало да се праве ни током периода неког од постова. ${ }^{5}$

И у случају појма венчање, као и случају веридбе, одговори су углавном звучали исто. Од 150 испитаних, њих 100 је одговорило да венчање представља највећу потврду љубави и знак да смо нашли особу са којом желимо да проведемо цео живот. Њих 27 је одговорило да венчање означава потврду везе пред Богом, док остатак није одговорио на ово питање. Примери:

„Венчање за мене представља највишу потврду љубави.“

„Венчање је потврда да ту особу са којом се венчавамо много волимо.“

„Венчање потврђује да смо нашли праву особу са којом желимо да проведемо цео свој живот.“

„енчање је потврда љубави пред Богом.“

„За мене је венчање дефинитивна и највећа потврда љубави према некој особи.“

„Венчањем потврђујемо да смо нашли некога кога много волимо и са киме желимо да оснујемо породицу и мислим да је то најлепши доказ љубави.“

3 http://www.spc.rs [2020-02-17]

4 Среда и петак су скоро увек посни дани, јер након великих постова, као што су на пример Васкршњи или Божићни пост, постоје недеље у којима су ова два дана разрешена, тј. верници не морају да се придржавају поста.

5 http://www.spc.rs [2020-02-17] 


\section{5 / ЗАКЉУЧАК}

Након сумираних резултата анкете, може се доћи до закључка да млади, без обзира на године и без обзира на то да ли су верници или не, да ли похађају веронауку или грађанско васпитање, на исти начин разумеју појам венчања и веридбе. За већину њих оба ова појма представљају нешто што учвршћује љубав и везу која постоји између две особе. Истина је да је веронаука у Србији као предмет уведена доста касно, али може се видети да има снажан утицај на младе у формирању мишљења и ставова према религији и вери. Не исти утицај који имају родитељи, али свакако незанемарљив.

Са тачке гледишта анкетираних произилази то да ни веридба, ни чин венчања немају у схватањима младих Срба сакраментални карактер, већ их пре повезују са традицијом која се у мањој или већој мери поштује, или су они нека врста потврде љубави од стране друге особе, поштовања његовог достојанства.

\section{THE MEANING OF ENGAGEMENT AND MARRIAGE IN THE ORTHODOX CHURCH FROM THE PERSPECTIVE OF YOUNG PEOPLE}

SUMMARY The present article introduces partial results of the research of the language used by young Christians in a "religious situation" (religious language), so it belongs to the field of the so-called theolinguistics. It deals with the views of young Orthodox Serbs concerning engagements and weddings. Both acts are not understood in a strictly religious sense as the administration of sacraments - the author does not only concentrate upon the act of ecclesiastical marriage, but also takes into account the meaning of traditions in a society which deviates from the patriarchal model of family. First, the author summarizes facts concerning theolinguistics as a linguistic subdiscipline and then, against the background of secondary literature, she presents the definitions and basic functions of religion mainly based on the opinions of Serbian researchers (theolinguists). Furthermore, it focuses on the institution of the family and its role in shaping the views of young people not only on the attitude towards God or the Church, but also to a fellow person, especially to their loved one. The analyzed material originated from a survey conducted in 2019.

\section{БИБЛИОГРАФИ]А}

I Кончаревић К., 2017, Језик и религија, Београд.

I Кончаревић К., 2015, Поглед у теолингвистику, Београд.

I Кубурић 3., 2008а, Религија, породииа, млади, Нови Сад, Београд.

I Кубурић 3., 2008b, Моћ идентификаиије, Нови Сад.

I Речник српског језика, 2011, Нови Сад.

\section{Интернет:}

I http://www.spc.rs/sr/vencanje [17.02.2020.]

I http://www.spc.rs/sr/цквенаверидба [17.02.2020.] 